\title{
EMPLOYEES' PRE-DISMISSAL RIGHT TO BE HEARD: THE MALAYSIAN AND THE ISLAMIC PERSPECTIVE
}

\author{
Junaidah Abd. Karim \\ Pusat Pengajian Perniagaan dan Pengurusan Maritim, Universiti \\ Malaysia Terengganu, Kuala Terengganu, Malaysia. \\ E-mail: junaidah@umt.edu.my \\ Tay Pek San \\ Law Faculty, University of Malaya, Kuala Lumpur, Malaysia. \\ E-mail: tayps@um.edu.my \\ Siti Zaharah Jamaluddin \\ Law Faculty, University of Malaya, Kuala Lumpur, \\ Malaysia. \\ E-mail: szjamal@um.edu.my \\ Abdul Muhsin Ahmad \\ Law Faculty, University of Malaya, Kuala Lumpur, Malaysia. \\ E-mail: amuhsin@um.edu.my
}

Abstract: It seemed to be a settled principle of law that before an employee can be dismissed from his job for misconduct, he must have a notice of the allegation against him and accorded a reasonable opportunity of being heard. However, this principle should berevisited in the light of two conflicting Federal Court's decisions pertaining to the mandatory issue of this right especially in the private sector employment in Malaysia. The curable principle as enunciated by Dreamland Corporation (M) Sdn. Bhd. v Choong Chin Sooi \& Anor [1988] 1 MLJ 111 has watered down the right of the employee to be heard as it was held in that case that the irregularity in holding a domestic enquiry is not fatal to the employer. He may justify the dismissal at the Industrial Court. Despite the existence of this principle, it should be emphasised that the right to a pre-dismissal hearing should be interpreted to be mandatory and not discretionary as there are two statutory provisions and constitutionally recognised rules of natural justice which may support this proposition. The mandatory effect of the domestic enquiry should be consistently upheld. With a view to enhance the employee's right and to ensure harmonious employer-employee relationship, it would be the purpose 
of this article to comparatively examine and learn how the same right is treated and regulated under the Islamic principle of justice and its application in two Islamic countries, namely Kingdom of Saudi Arabia and the UAE. Apart from narrowing down the gap in the Islamic knowledge on the administration of justice in dismissal cases, this article may also contribute in idea on how to harmonise the current employment laws and the Sharia.

Keywords: Workers, Dismissals, Misconduct, Natural justice, Islam.

Abstrak: Ianya seolah-olah telah menjadi satu prinsip undangundang yang mantap di mana sebelum seseorang pekerja boleh dipecat daripada pekerjaannya kerana salah laku, dia mestidiberikan notis pertuduhan terhadapnya dan peluang yang munasabah untuk didengar. Walau bagaimanapun, prinsip ini perlu dikaji semula dengan mengambil kira dua keputusan Mahkamah Persekutuan yang bercanggah mengenai isu mandatori hak ini terutamanya dalam sektor pekerjaan swasta di Malaysia. Prinsip 'pembetulan'(curable) seperti yang dikemukakan oleh Dreamland Corporation (M) Sdn. v Choong Chin Sooi \& Anor [1988] 1 MLJ 111 telah mengurangkan hak pekerja untuk didengar kerana telah diputuskan di dalam kes tersebut bahawa ketidakteraturan dalam mengadakan siasatan domestik tidak 'membawa padah' (fatal) kepada majikan. Dia boleh menjustifikasikan pemecatan itu di Mahkamah Perusahaan. Walaupun wujudnya prinsip ini, perlu ditekankan bahawa hak untuk didengar sebelum pemecatan harus ditafsirkan sebagai mandatori dan tidak bergantung kepada budi bicara kerana terdapat dua peruntukan statut dan peraturan keadilan semulajadi yang diiktiraf perlembagaan yang boleh menyokong prinsip ini dan kesan mandatori dalam siasatan domestik haruslah ditegakkan secara konsisten. Dengan maksud untuk meningkatkan hak pekerja dan memastikan perhubungan majikan dan pekerja yang harmoni, adalah menjadi tujuan artikel ini untuk mengkaji secara perbandingan dan mempelajari bagaimana hak yang sama diperlakukan dan diatur di bawah prinsip keadilan Islam dan aplikasinya di dua negara Islam, iaitu Kerajaan Arab Saudi dan UAE. Selain daripada merapatkan jurang pengetahuan Islam mengenai pentadbiran keadilan di dalam kes-kes pemecatan, artikel ini juga boleh menyumbangkan idea tentang bagaimana untuk mengharmonikan undang-undang pekerjaan dan Syariah atau menjadikannya patuh Syariah melalui pindaan statutori yang dicadangkan.

Kata Kunci: Pekerja, Pemecatan, Salah laku, Keadilan semulajadi, Islam. 


\section{INTRODUCTION}

The right to be heard or audi alteram partem is a principle of natural justice that no man should be condemned unheard or both sides to a dispute must be heard. Natural justice is defined as "justice administered without reference to statute in the decision of the law court where the judge is being guided by what is called conscience of the natural sense of what is right or wrong." (Balakrishnan \& Balakrishnan, 2007). ${ }^{1}$ In the employment context, this may mean that even if there is no statutory provision to impose the giving of the right to be heard to an employee accused of a certain misconduct, under the doctrine of procedural fairness ${ }^{2}$ the right must be observed during domestic enquiries in the private sector and similarly, in disciplinary proceedings in the public sector before an employee is penalised. The normal range of requirements under the natural justice of the right to be heard rule are the requirement of the notice of allegation, a consideration of the need for an oral hearing, disclosure of evidence, the opportunity of cross examination and the need for legal representation. ${ }^{3}$

Despite what seems to be the above commonly held view, the issue of whether or not the holding of a domestic enquiry to give an employee the right to be heard is mandatory or not is still unsettled in Malaysia, particularly in the private sector employment. This is due to the two contradictory Federal Court's cases deciding on this matter. The first case of Dreamland Corporation (M) Sdn. Bhd. v Choong Chin Sooi \& Anor ${ }^{4}$ held that failure to conduct an enquiry at the workplace prior to termination was not fatal to the company's case. Even though there was a breach of the rules of natural justice, it could be cured in a subsequent hearing of the matter when it is referred to the Industrial Court. On the other hand, the second case of Said Dharmalingam bin Abdullah v Malayan Breweries ${ }^{5}$ decided that the failure on the part of the employer to hold a

Balakrishnan, M., \& Balakrishnan, P. (2007). Misconduct, domestic enquiry and the rules of natural justice in the context of Malaysian employment relations, Malayan Law Journal Articles (6), 149-163.

2 Sundra-Karean, V. (2012). Employment law and theory. Malaysia. The Malaysian Current Law Journal Sdn Bhd., 165.

Ibid.

[1988] 1 MLJ 111.

[1997] AMR 1063. 
pre-dismissal enquiry could not be cured by the hearing before the Industrial Court. The right was treated as mandatory by this case, at least for those who were covered under the Employment Act $1955^{6}$. Therefore, failure to observe the procedural right would enable the employee to claim for reinstatement to his former position. ${ }^{7}$ When the curable principle in Dreamland was extended in the subsequent case of Milan Auto Sdn Bhd v Wong Seh Yen ${ }^{8}$ to employees covered by the Employment Act 1955, a real confusion occurred. As a result, an employee may not expect equal and consistent treatment of the law with another employee in any dismissal proceedings anymore and an unscrupulous employer may escape any liability whatsoever for dismissing his employee without conducting a domestic enquiry prior to that. The Industrial Court has grappled with this mandatory issue for years and at times arrived at conflicting decisions (Ayadurai, $1998^{9}$; Maimunah, $2013^{10}$ ). This unsatisfactory state of law should not be allowed to continue. There is an overwhelming number of unfair dismissal disputes based on misconduct as can be seen from the statistics in Table 1 below.

In light of the current issue above, this article will, in turn, examine how the same pre-dismissal right is treated based on the Islamic principle of justice and its application and discuss the possibilities of adapting or adopting the Islamic approach in order to resolve it. This study, particularly involves a comparative analysis on the right to be heard in the Malaysian employment context with the Islamic

6 It should be noted that the Federal Court differentiated Said Dharmalingam with Dreamland because the employee in Said Dharmalingam fell under the purview of the Employment Act 1955 where there was a specific statutory due enquiry requirement of s. 14(1) applicable to him.

7 S 20 (1) Industrial Relations Act 1967. If proven to be impracticable, applying s 30 (6) of the same Act, compensation in lieu would be granted as s 30(6) states "in making its award, the Court shall not be restricted to the specific relief claimed by the parties or to the demands made by the parties in the course of the trade dispute or in the matter of the reference to it under ss. 20(3) but may include in the award any matter or thing which it thinks necessary or expedient for the purpose of settling the trade dispute or the reference to it under ss. 20(3)."

[1995] 3 MLJ 537.

9 Ayadurai, D. (1998). Industrial relations in Malaysia. Kuala Lumpur: Malayan Law Journal Sdn Bhd, at 160.

10 Maimunnah Aminuddin. (2013). Malaysian industrial relations \& employment law, $8^{\text {th }}$ ed. Malaysia: McGraw Hill Education (Malaysia) Sdn. Bhd., at 257. 
principle of justice and its application. Based on the Sharia law, the employee's pre-dismissal right to be heard is mandatory except where there is an admission of guilt on the part of the employee. This mandatory effect is clearly stipulated in the statutory provisions of the Islamic countries selected. This study may contribute in narrowing down the gap in the Islamic knowledge especially on the administration of employees' procedural fairness rules before dismissal. As amendments to the relevant laws are time consuming, another separate research on the practicality of harmonising the current labour laws and Sharia by interpretation in accordance to the Islamic concept of Siyasah Syar'iyyah ${ }^{11}$ and Maslahah ${ }^{I 2}$ may be required to enhance the employees' pre-dismissal right.

Table 1. Analysis of Industrial Court's Awards for Dismissal Cases $(2009-2015)^{13}$

\begin{tabular}{lrrrrrrr}
\hline $\begin{array}{l}\text { TYPES OF } \\
\text { DISMISSAL }\end{array}$ & $\mathbf{2 0 0 9}$ & $\mathbf{2 0 1 0}$ & $\mathbf{2 0 1 1}$ & $\mathbf{2 0 1 2}$ & $\mathbf{2 0 1 3}$ & $\mathbf{2 0 1 4}$ & $\mathbf{2 0 1 5}$ \\
\hline Constructive & 140 & 135 & 91 & 96 & 86 & 87 & 81 \\
Misconduct & 613 & 608 & 639 & 540 & 567 & 457 & 477 \\
Retrenchment & 114 & 67 & 90 & 62 & 91 & 59 & 57 \\
Others & 328 & 479 & 640 & 735 & 818 & 545 & 527 \\
\hline TOTAL & $\mathbf{1 1 9 5}$ & $\mathbf{1 2 8 9}$ & $\mathbf{1 4 6 0}$ & $\mathbf{1 4 3 3}$ & $\mathbf{1 5 6 2}$ & $\mathbf{1 1 4 8}$ & $\mathbf{1 1 4 2}$ \\
\hline
\end{tabular}

11 'Siyasah Syar 'iyyah' is a broad doctrine of Islamic law which authorises the ruler to determine the manner in which the Sharia should be administered. It allows the ruler to take discretionary measures, enact rules and initiate policies as he deems are in the interest of a good government, provided that no substantive principle of Sharia is violated. Refer Mohamad Hashim Kamali (1989). Siyasah Shar'iyah or the Policies of Islamic Government. The American Journal of Islamic Social Sciences (6:9), 59-80.

12 Maslahah' is defined as "public interest; a basis of law. According to necessity and particular circumstances, it consists of prohibiting or permitting something on the basis of whether or not it serves the public's benefit or welfare. The concept of public interest can be very helpful in cases not regulated by the Quran, Sunnah, or qiyas (analogy). Here, equitable considerations can override the results of strict analogy, taking into account the public's welfare." Refer J.L. Esposito. 'The Oxford Dictionary of Islam: Oxford Islamic studies Online' http://www.oxfordislamicstudies.com/article/opr/t125/e1459, (accessed 24 July 2016).

13 Maziah Maon, Assistant Registrar, Industrial Court of Malaysia, Kuala Lumpur, "Re: Statistics of Analysis of Awards of Dismissal Cases", E-mail to Junaidah Abd. Karim, 1 June 2016. 


\section{EMPLOYEES' PRE-DISMISSAL RIGHT IN MALAYSIA}

Public servants' pre-dismissal right to be heard in Malaysia is clearly mandatory. Their right is expressly guaranteed by the Malaysian Constitution art 135(2) where it provides that "no member of such a service as aforesaid (public service as defined in art 132) shall be dismissed or reduced in rank without being given a reasonable opportunity of being heard..." This right is further emphasised by reg 34(1) of the Public Officers (Conduct and Discipline) (Amendment) Regulations 2002 (P.U. (A) 246/2002) ) $^{14}$ and procedurally regulated by reg 37 of the same regulation. It is clear-cut that the right is mandatory in the public service as evidenced in Surinder Singh Kanda v Government of the Federation of Malaya ${ }^{15}, G P \&$ Anor v Alan Noor bin Kamat ${ }^{16}$ and Phang Moh Shin v Comm. of Police ${ }^{17}$. In Surinder Singh Kanda, the Privy Council defined the basic components of a right to be heard and highlighted that both sides in dispute must be heard. It was stated in that case that:

If the right to be heard is to be a real right which is worth anything, it must carry with it a right in the accused man to know the case which is made against him. He must know what evidence has been given and what statements have been made affecting him, and then he must be given a fair opportunity to correct or contradict them. This appeared in all the cases from the celebrated judgment of Lord Loreburn, L.C. in Board of Education v. Rice down to the decision of their Lordships' Board in Ceylon University v. Fernando. It follows, of course, that the judge or whoever has to adjudicate must not hear evidence or received representations from one side behind the back of the other. The Court will not enquire whether the evidence or representations did work to his prejudice. Sufficient that they might do so. The Court will not go into the likelihood of prejudice. The risk of it is enough.

\footnotetext{
14 Regulation 34 (1) states that "subject to subregulation (2), no officer shall be dismissed or reduced in rank in any disciplinary proceedings under this Part unless he has first been informed in writing of the grounds on which such action is proposed and he has been afforded a reasonable opportunity of being heard. [1962] 1 MLJ 168, [1962] 28 MLJ 169, P.172.

[1988] 1 MLJ 260.

[1967] 2 MLJ 186.
} 
In contrast, it is uncertain whether or not the employees in the private sector employment have a pre-dismissal right to be heard due to the undesirable effect of the case of Dreamland as extended by Milan Auto. The uncertain application of the curable principle has resulted in confusion in the Industrial Court in making its award with regard to the mandatory effect of the right. Subsequently, there are three splitting trends in the Industrial Court cases (Kamal Halili, 2001). ${ }^{18}$ First, cases which decided that the absence of domestic enquiry is curable. Second, cases where the court reprimanded the employer who did not conduct the domestic enquiry but still continued to hear the case on merit and decided whether or not the dismissal was with just cause and excuse. Third, cases that decided that domestic enquiry must be held before dismissing the employee. These splitting trends can be used as an evidence to support Anantaraman's earlier claim that the Malaysian case law governing procedural rectitude in dismissal for misconduct is in the state of flux. ${ }^{19}$

In spite of the current position above, it may be argued that the right to a pre-dismissal hearing or better known as domestic enquiry in the private sector employment should be interpreted to be mandatory and not discretionary. There are two main statutory provisions and the common law rules of natural justice in support of this proposition. In addition to that, it may also be argued that the application of the curable principle should be very limited if not discarded at all due to its weak foundation and the mandatory effect of the domestic enquiry should be consistently upheld.

The main statutory basis for the mandatory effect of domestic enquiry can be found under s 14(1) of the Employment Act 1955 (Act 365) where it stipulates:

An employer may, on the grounds of misconduct inconsistent with the fulfilment of the express or implied conditions of his service, after due enquiry

(a) dismiss without notice to the employee,

(b) downgrade the employee, or

(c) impose any other lesser punishment as he deems just and fit. And where a punishment of suspension without wages is imposed, it shall not exceed a period of two weeks.

18 Kamal Halili Hassan.(2001). Siasatan domestik: Trend dan pendirian mahkamah perusahaan, 1995-2001. ILR (4), i-x.

19 Anantaraman, V. (1997). Malaysian industrial relations, law \& practice. Selangor, Malaysia: Universiti Putra Malaysia Press, at 269. 
It is clear that this provision makes it necessary to hold a 'due enquiry' prior to the infliction of punishment for misconduct and the Industrial Court has consistently applied so in its awards. ${ }^{20}$ However, this provision offers limited protection as it applies only to 'employee' as categorised by the Act and amongst others, ${ }^{21}$ whose monthly salary does not exceed RM2000 per month.

The second statutory proviso that could be the basis for the mandatory effect of the right is s 20(1) of the Industrial Relations Act 1967 (Act 177). Theoretically, the spectrum of s 20(1) of the Industrial Relations Act 1967 is broader than s 14(1) Employment Act 1955 as the Act protects all 'workmen' 22 , regardless of their salary, for as long as they are under a 'contract of service'. S 20(1) of the Industrial Relations Act 1967 provides:

Where a workman, irrespective of whether he is a member of a trade union of workmen or otherwise, considers that he has been dismissed without just cause or excuse by his employer, he may make representations in writing to the Director General to be reinstated in his former employment; the representations may be filed at the office of the Director General nearest to the place of employment from which the workman was dismissed.

Even though there is no express word requiring any enquiry, the above provision requires that a dismissal be with 'just cause and excuse'. What exactly 'just cause and excuse' means is not clear but the persistent question to be answered here is whether the phrase 'just cause and excuse' requires compliance with the 'procedural

$20 \quad$ See for example Rumah Kebajikan Kanak-Kanak Taiping v Kamal Bhai GL Naidu (1995) 1 ILR 92, Nagai Metal Traders Sdn Bhd Johor v Ramanaidoo Mallanaido [1997] 2 ILR 887, Pro Ads \& Co v Lo Lai Choo [1997[ 3 ILR 1025 and Poh Loy Earthworks Sdn Bhd v Mohd Nasaruddin Taib [1997] 3 ILR 608.

21 The Act is applicable to those who are earning more than RM2000 if the 'employee' falls within the ambit of specific jobs as mentioned in s 2(1) First Schedule, Employment Act 1955.

22 According to s 2 of the Industrial Relations Act 1967, 'workman' means “any person, including an apprentice, employed by an employer under a contract of employment to work for hire or reward and for the purposes of any proceedings in relation to a trade dispute includes any such person who has been dismissed, discharged or retrenched in connection with or as a consequence of that dispute or whose dismissal, discharge or retrenchment has led to that dispute." 
fairness' as well as the 'substantive fairness' rule. The Federal Court in Wong Yuen Hock v Syarikat Hong Leong Assurance Sdn. Bhd. ${ }^{23}$, in following Dreamland, was of the view that the wording of $\mathrm{s}$ 20(1) and s 20(3) ${ }^{24}$ of the Industrial Relations Act 1967 limits the Industrial Court's jurisdiction to review cases on substantive merit only and not to consider whether or not the dismissal was carried out in accordance with the rules of natural justice or procedural fairness.

Before scrutinising the decision of the cases above, the researcher first laid down the facts and the reasoning behind them. In Dreamland, Choong, the employee, a project manager, was dismissed with immediate effect without any enquiry because of his persistent casual and indifferent attitude towards his responsibilities and for provoking and instigating dissatisfaction among fellow workers. The first respondent argued that his dismissal was without just cause or excuse and contrary to the principles of natural justice. The reference was made to the Industrial Court under s 20(3) Industrial Relations Act 1967. The Industrial Court, after its own enquiry, held that Choong's dismissal was justified as he had committed misconduct but as there was no enquiry held by the employer, the effective date of dismissal would be the last date of enquiry and he was entitled to back wages. The Industrial Court interpreted the words "just cause or excuse" under s 20(1) Industrial Relations Act 1967 to mean not only the reason for the dismissal but also the manner of the dismissal, particularly the rules of natural justice. The award later was referred to the High Court on two questions of law: (a) Does the Industrial Court have jurisdiction to award compensation to a workman whose dismissal has been upheld by the court?, and (b) does it have jurisdiction to amend the date of dismissal? The Application to the High Court was dismissed and the appellant company appealed to the Supreme Court. The appeal was allowed. The Supreme Court held that the workman was lawfully dismissed as held by the Industrial Court. Neither the Industrial Court nor the High Court was correct in amending the date of dismissal and awarding the compensation as a consequence of such an amended

[1995] 3 CLJ 344.

24 S 20(3) Industrial Relations Act 1967 states that "upon receiving the notification of the Director General under subsection (2), the Minister may, if he thinks fit, refer the representations to the Court for an award." 
date, as both matters were outside their jurisdiction in an enquiry under s 20(3) of the Industrial Relations Act 1967.

The reasoning from the Supreme Court in Dreamland seems to suggest that where no enquiry has been held before dismissal, the threshold jurisdiction of the Industrial Court depends on the reference by the Minister to find: (a) whether there was enough evidence to show misconduct, and (b) whether the dismissal was for a 'just cause or excuse'. It would be a jurisdictional error to look into the question of whether or not the dismissal was preceded by any enquiry. The defect in the enquiry or the procedural irregularity can be cured when the case is referred to the Industrial Court where the case will be heard afresh. The Supreme Court embraced the curable principle from the Indian case of Workman of the Motipur Sugar Factory Private Limited v The Motipur Sugar Factory Private Limited $^{25}$ as the Court cited:

Where an employer has failed to make an enquiry before dismissing or discharging a workman it is open to him to justify his action before the Tribunal by leading all relevant evidence before it. The entire matter would be open before the Tribunal. It will have jurisdiction not only to go into the limited questions open to a tribunal where domestic enquiry has been properly held, but also to satisfy itself on the facts adduced before it by the employer whether the dismissal or discharge was justified. The important effect of omission to hold an enquiry is merely that the Tribunal would not have to consider only whether there was a prima facie case but would decide for itself on the evidence adduced whether the charges have really been made out.

It is clear from Dreamland that as a general principle, failure to hold an enquiry is not fatal to the employer as it can be cured. The employer would be entitled to justify his action before the Industrial Court.

The curable principle as reiterated by Dreamland was applied in the case of Wong Yuen Hock. The Federal Court in Wong Yuen Hock reaffirmed that the Industrial Court was not competent to declare the dismissal void purely on the ground of failure to hold

$25 \quad$ AIR 1965 SC 1803. 
a domestic enquiry, taking into consideration the function of the Industrial Court to deal with the "substantial merits of the case with urgency and without regard to technicalities". ${ }^{26}$ In Wong Yuen Hock, Wong, the employee, a claims manager with a basic salary of RM3600 a month, was sacked after investigations on irregularities in the sale of two motor car wrecks without affording him the right to be heard in a domestic enquiry. The right was stipulated in his contract of employment. A case of wrongful dismissal was referred by the Minister to the Industrial Court under s 20(3) of the Industrial Relations Act 1967. The Industrial Court held that Wong's was wrongfully dismissed solely on the procedural ground that he had not been given the opportunity to be heard in any domestic enquiry. The Industrial Court awarded Wong compensation in lieu of reinstatement. The quantum was reduced because of Wong's misconduct. Wong, who was dissatisfied with the reduced amount, and his employer, who was aggrieved by the whole award, applied to the High Court for an order of certiorari to quash the award. Both applications were dismissed and they both appealed. The Federal Court allowed Hong Leong's appeal to the extent of quashing the part of award, which held that Hong Leong's failure rendered Wong's dismissal without just cause or excuse. Wong's appeal was dismissed. The Federal Court in this case, emphasised the function of the Industrial Court in dealing with reference under s 20(3) of the Industrial Act 1967, which is to deal with the substantial merits of the case without regard to technicalities. Therefore, the Industrial Court had to determine whether the misconduct was in fact committed first and then whether it constituted just cause or excuse for the dismissal. ${ }^{27}$ The Industrial Court was not competent to declare the dismissal void on the ground of failure to hold a domestic enquiry as it was a matter outside the terms of reference by the Minister. ${ }^{28}$ Accordingly, it was held that failure to comply with natural justice prior to dismissal at the workplace level was curable at the rehearing by the Industrial Court. The Federal Court stated that:

The Industrial Court is an independent statutory body capable of reaching a fair result by fair means on all matters referred to it. Therefore, if there had been a breach of natural justice by the employer at the initial stage, it could be cured at the

\footnotetext{
$26 \quad$ Id. at 754 .

$27 \quad$ [1995] 2 MLJ 753 at 762.

28 Ibid.
} 
rehearing by the Industrial Court. The Industrial Court had committed a jurisdictional error when it held that Wong was dismissed without just cause and excuse purely on the basis of failure to hold a domestic enquiry. ${ }^{29}$

The Court in Wong Yuen Hock also indicated that the curable principle applies to all cases, including those which are covered under the ambit of the Employment Act. In the words of Mohd Azmi FCJ:

The principle that an initial breach of natural justice by the employer could be cured by the Industrial Court enquiry, applies to all cases, regardless of whether the claimant is an employee within the meaning of the Employment Act 1955. ${ }^{30}$

The statements above may be argued to be an obiter dicta only since the claimant in that case, Wong, was not an 'employee' under the Employment Act 1955. However, it is so unfortunate for the employee that this obiter dicta had turned into a ratio decidendi when it was applied and extended in Milan Auto, a dismissal case where the employee was covered by the Employment Act.

In Milan Auto, the respondent was a mechanic with a monthly salary of RM600. He was dismissed without a domestic enquiry based on the allegations that he was undisciplined, had on several occasion slept during working hours, taken leave without approval and refused to see the superior when requested to do so. He made a representation that he had been dismissed without just cause or excuse by the appellant and the Minister referred the case to the Industrial Court under s 20(3) of the Industrial Relations Act 1967. The Industrial Court decided in favour of the respondent as failure to hold an enquiry was a breach of statutory duty under s 14(1) of the Employment Act 1955 and the principle of natural justice. It was sufficient to constitute a dismissal without just cause or excuse. It was also unnecessary to determine whether or not the alleged misconduct, if established, constituted a just cause or excuse for dismissal. The appellant applied to the High Court to quash the award but it was dismissed. The appellant appealed and the Federal

[1995] 2 MLJ 753 at 754.

30 Ibid. 
Court allowed the appeal. The Federal Court once again emphasised the function of the Industrial Court under s 20 of the Industrial Relations Act 1967, to deal with the substantial merit of the case. It was held that failure to determine whether the alleged misconduct had been established and whether the proven misconduct constituted just cause or excuse for the dismissal would be a jurisdictional error. The curable principle was reemphasised and extended in this case to cover all private sector employees, regardless of their salary and whether or not they fell under the ambit of the Employment Act 1955. In the words of Mohamed Azmi FCJ:

The breach of natural justice in not holding a statutory or contractual domestic enquiry was 'curable' by an enquiry held by the Industrial Court itself. The principle of curable is not limited to a certain category of workmen depending on their salaries. In the absence of clear words by the Parliament, neither the requirement of due enquiry before dismissal in s 14(1) of the Employment Act 1955 for employees whose earning did not exceed RM1,250 per month, nor the subsequent amending Acts were intended to alter this policy of the law. ${ }^{31}$

It should be stressed here that when the curable principle from Dreamland was further extended by Milan Auto, the effect on the employee became worse to the extent that it might be blatantly said that all private sector employees, regardless of whether or not they were protected under the Employment Act 1955, did not have thus far the right to a pre-dismissal enquiry. As ridiculous as it may sound, the employers were not then under any legal obligation to follow any procedure before dismissing the employees. The curable principle has watered down the right of the employee despite the existence of the statutory and contractual requirement to hold such enquiry as evidenced in Milan Auto as well as Wong Yuen Hock.

Contrary to Dreamland, Wong Yuen Hock and Milan Auto, the case of Said Dharmalingam marked a significant departure. In this case, the employee, a cooler operator, was an 'employee' under the Employment Act 1955. He was found guilty of attempted theft from the brewery at the pre-dismissal enquiry and was dismissed by the brewery manager with immediate effect. He was not invited to make a

[1995] 3 MLJ 537 at 359. 
plea in mitigation before the imposition of the punishment. The main question of law in Said Dharmalingam was whether the appellant who was an 'employee' within the meaning of the Employment Act 1955 would be entitled to have his dismissal declared null, void and of no effect if the procedural safeguards provided by the law had not been observed at the pre-dismissal inquiry at the workplace level. ${ }^{32}$ The employee argued that there was a breach of audi alteram partem rule of natural justice when he had not been given the opportunity to make a submission in mitigation. On the other hand, the employer's disciplinary guidelines provided that attempted theft was a serious offence that dismissal was mandatory upon being found guilty. The right to 'due enquiry' was held to include the opportunity to present arguments on liability and mitigation in punishment. ${ }^{33}$ However, since no other punishment was possible in this case, considering the circumstances of the case, it would be a useless formality to accord the right to mitigation and thus, the employee's appeal was dismissed.

With regard to the main question of law in the above case, the Federal Court held that an employee within the ambit of the Employment Act 1955 has a statutory right to 'due enquiry' by his employer before being dismissed. ${ }^{34}$ Edgar Joseph Jr. FCJ in delivering the judgement stated:

Speaking generally, where the relationship is that of master and servant, we are normally in the field of common law of contract, and so, the principle of administrative law-which, of course, must include the fundamental rule of natural justice expressed in the Latin maxim audi alteram partem (hear the other side) -would not apply. On the other hand, where the employment is in the public sector, or where statutory or other protection is conferred, procedural safeguards will have to be observed..$^{35}$...When, as here, a claimant is an employee within the meaning of the Act, he has by s 14(1) thereof a statutory right to 'due enquiry' by his employer, and so, the approach of the Industrial Court or for that matter, the High Court, in considering the

32 Ibid.

33 Ibid.

[1997] 1 MLJ 352, at 353.

Id. At 358. 
question whether the claimant had been dismissed without just cause or excuse, would be to examine the decision not just for substance but for process as well. ${ }^{36}$

It may be established from the above statements that the right to a pre-dismissal enquiry must be observed if the employee is in the public service or there is a statutory or other protection conferred on the employee. Where there is a clear statutory requirement such as s 14(1) of the Employment Act 1955 to protect an employee, in considering whether his dismissal is without just cause and excuse, both the substance and the procedures must be taken into account. His right to a pre-dismissal enquiry is therefore mandatory and the curable principle should not apply. This case is a complete opposite of Milan Auto. It should be also be emphasised here that in Said Dharmalingam, the cases of Dreamland and Wong Yuen Hock were distinguished, as the employees in those two cases were not 'employees' under the Employment Act 1955. However, the case of Milan Auto was left out from the discussion. Otherwise, it would be very hard to reconcile Said Dharmalingam and Milan Auto as the employees in these two cases were both 'employees' within the ambit of the Employment Act 1955. The conflicting decision of these two cases with regard to the application of the curable principle, actually, has been the major cause of the earlier mentioned confusion and chaos at the lower courts. The researcher is of the opinion that in considering future similar cases, the case of Said Dharmalingam should be more preferable than Milan Auto as the decision in Milan Auto was based on a weak foundation of the ratio decidendi in Wong Yuen Hock.

The application of the curable principle in Malaysia may be argued to be inconsistent with the provisions on how the Industrial Court shall make its award. The Industrial Court is required to decide a dismissal case by reference not only to contractual rights and obligations of the parties but also to what is fair and right on the ground of equity as stated in s 30(5) of the Industrial Relations Act 1967. The section provides that "the Court shall act according to equity, good conscience and the substantial merits of the case without regard to technicalities and legal form." What equity requires was

$36 \quad$ [1997] 1 MLJ 352, at 363. 
explained quite fairly by Weddel \& Co. Ltd. v Tepper ${ }^{37}$ where the employer had to give a fair opportunity to the employee to defend himself and investigate the case reasonably. Accordingly, s 20(1) of the Industrial Relations Act 1967 should be construed to require not only substantive fairness compliance but also procedural fairness before dismissing a workman. This view was supported by Edgar Joseph Jr. FCJ in his obiter in Said Dharmalingam ${ }^{38}$ where he stated that the reasonableness of a dismissal may depend on the procedure followed and s 20(1) of the Industrial Relations Act 1967 should be interpreted as providing the right to a hearing. ${ }^{39}$

Turning to the other basis that requires an employer to hold a predismissal enquiry and ignore the curable principle, is the common law rule of natural justice. The first case that specifically mentioned that an employee in the private sector employment has the right to a hearing that conforms to the principles of natural justice ${ }^{40}$ is Syarikat Great Eastern Life Assurance Bhd.v Kesatuan Sekerja Kebangsaan Pekerja-pekerja Perdagangan ${ }^{41}$. This principle was extended from the case of Surinder Singh Kanda v Government of the Federation of Malaya ${ }^{42}$, which initially was applicable to public servants only. The Industrial Court in Syarikat Great Eastern Life Assurance Bhd. said inter alia:

Before the service of an employee can be terminated on the grounds that he has committed some misconduct which deserves the punishment of dismissal, he should be adequately informed of the accusations made against him and he should be given a fair opportunity to correct or contradict them. One of the principles of natural justice is that no one shall be condemned unheard..."43

37 Weddel \& Co. Ltd.v Tapper [1980] IRLR 96.

38 The matter was brought before the High Court to seek a declaration on the breach of s 14(1) Employment Act 1955 and not under s 20 Industrial relations Act 1967.

39 Said Dharmalingam bin Abdullah v Malayan Breweries (Malaya) Sdn Bhd [1997] MLJ 352 at p. 361.

40 Pathmanathan, N., Kanagasabai, S. K., \& Alagaratnam, S. (2003). Law of dismissal. Singapore: CCH Asia Pte Limited, at 214.

41 Industrial Court Award No.21 of 1969.

$42 \quad$ [1962] 28 MLJ 169.

43 Cited in Hew S. K. (2013). Dismissal: Salient point to ponder before industrial court proceedings in Malaysia ( $2^{\text {nd }}$ ed.). Selangor, Malaysia: Leeds Publication, at 432-433. 
The requirement to comply with the rules of natural justice was further strengthened by the pronouncement in Tan Tek Seng v Suruhanjaya Perkhidmatan Pendidikan \& Anor ${ }^{44}$ which raised procedural fairness or the right to natural justice to a constitutional footing. The Court of Appeal in Tan Tek Seng directly addressed the issue of procedural fairness and its relation to the fundamental rights enshrined under art 5(1) and art 8(1) of the Malaysian Constitution. Gopal Sri Ram JCA indicated in this case that:

...the expression 'law' which appears in art 5 (1) and $8(1)$ of the Federal Constitution includes procedural law and, in particular, any procedure prescribed by written law. If a particular procedure prescribed by written law is found to be arbitrary or unfair or the procedure adopted in a given case is held to be unfair, then generally speaking, it must be struck down as offending art 5(1) read with art 8(1)...in the context of art 5(1), if an unfair procedure is resorted to in deprivation of a person's life or liberty, then the decision and the procedure are liable to be struck down. 45

Raja Azlan Shah J in the much earlier case of Che Ani bin Itam v Public Prosecutor ${ }^{46}$ had also affirmed that:

'Law' in the context of such constitutional provision as Articles 5, 8 and 13 of the Constitution refers to a system of law which incorporates those fundamental rules of natural justice that had formed part and parcel of the common law of England that was in operation at the commencement of the Constitution.

The pronouncement in Tan Tek Seng ${ }^{47}$ which was reaffirmed by the Federal Court in $R$ Rama Chandran ${ }^{48}$ raised the right to procedural fairness to a constitutional level where an individual's livelihood can only be deprived in accordance to it. Hence, the rule of natural

$44 \quad$ [1996] 1 MLJ 261.

$45 \quad$ Id. at 287.

46 [1984] 1 MLJ 113, at 114.

$47 \quad$ Tan Tek Seng $v$ Suruhanjaya Perkhidmatan Pendidikan \& Anor [1996] 1 MLJ 261.

$48 \quad R$ Rama Chandran v The Industrial Court of Malaysia and Anor [1997] 1 MLJ 145. 
justice should always be applicable in an employee's dismissal proceeding, be it in the private or public service. The rule of natural justice is primarily concerned with hearing the other side before a man is condemned and should be applied before an employee is dismissed. It is not meant to be a guiding rule for the rectifying process when the case is referred to the Industrial Court. Thus, it must be complied with at the pre-dismissal proceedings. It was correctly deduced by Sundra-Karean (2012) that since Tan Tek Seng has elevated common law principles of natural justice in Malaysia to a constitutional footing, it is arguable that the cases decided before that, which held that it was not mandatory to conduct a pre-dismissal enquiry, are no longer good law. ${ }^{49}$

It can also be argued that except as expressly provided by the statutes, the pre-dismissal enquiry should be mandatory and there should not be any room for curable principle to work. This is based on three more reasons. First, the curable principle and its application in Malaysia is based on a too broad reiteration of the Indian Motipur's case. ${ }^{50}$ Second, the mandatory statutory requirement to a pre-dismissal enquiry of s 14(1) Employment Act 1955 should not simply be exempted by the curable principle at common law, as the public policy also forbids parties to breach their statutory duties. ${ }^{51}$ Based on this reason, it is strongly recommended that for future similar cases, Said Dharmalingam should be referred to instead of Milan Auto. Third, the basic principle of industrial jurisprudence requires the employer to prove the workman's guilt and not the workman who must prove himself not guilty ${ }^{52}$ and thus, the predismissal enquiry must be carried out by the employer before any dismissal.

Perhaps, the first reason needs further elaboration. The Indian Supreme Court has categorised cases of dismissal for misconduct into two: (a) cases where an enquiry is not treated as an empty formality but an essential requirement to the legality of the disciplinary order, and (b) cases where the dismissal may still be justified by the employer before the Tribunal by adducing evidence in the event the employer has not conducted an enquiry or the enquiry is found to

\footnotetext{
49 Sundra-Karean, op. cit., 146.

50 Workman of the Motipur Sugar Factory Private Limited v The Motipur Sugar Factory Private Limited (1965) AIR SC 1803.

51 Sundra-Karean, op. cit., 142.

52 Stamford Executive Centre v Puan Dharsini Ganesan 1 ILR 101.
} 
be invalid..$^{53}$ The first category of cases reflects the basic rule as it should be and the second category the exceptions to the rule where the pre-dismissal enquiry may be dispensed in acceptable situations. The Motipur case, according to Anwarul Yaqin (1999), falls into the second category where the employer may dispense with the enquiry where "it may not be practically possible or expedient to hold an enquiry." 54

For a better understanding, it might be useful to compare the facts of the cases first. In Motipur, 119 workmen started a 'go-slow' practice in the production, which could cause a breakdown of the mill. The Supreme Court decided that any insistence on a predismissal enquiry was not a proper course as it involved so many workers. It would undeniably cause delay and other industrial dismissal disputes after the holding of such an enquiry. Thus, the employer in that situation may justify on the evidence before the Industrial Tribunal that the dismissal was for a just cause. On the contrary, the alleged misconduct in Dreamland where the employee provoked and instigated dissatisfaction amongst fellow workers, was not extraordinary or peculiar enough as in Motipur to warrant the exception. There was no imminent 'danger' to the company and there was only one employee involved in the misconduct. A domestic enquiry should have been held in that instance. Similarly, in subsequent cases of Wong Yuen Hock where the employee, an insurance claim manager, had improperly sold himself two motor wrecks and in Milan Auto where the employee, a mechanic, was accused of amongst others, indiscipline, being unproductive and sleeping on duty, the facts were not extraordinary or peculiar enough as in Motipur. Therefore, domestic inquiries should have been held first prior to dismissal of the employees to establish the misconducts.

\section{THE ISLAMIC PERSPECTIVE}

Having discussed the state of the laws relating to the pre-dismissal right to be heard in Malaysia, the focus will now be turned to the Islamic perspective on the right. It would be examined based on the

\footnotetext{
53 Anwarul Yaqin (1999). Procedural fairness in dismissals for misconduct: Some reflections on judicial trends in Malaysia. MLJA (2), 140-156, at 142.

54 Ibid.
} 
Islamic principle of justice, the penumbra of the right to procedural fairness or more specifically, the right to be heard and followed by its application.

The review of the current labour laws to ensure that they are in harmony with the Islamic principles and application is necessary because of two reasons. The first is to fulfil Muslims' expectations and concerns that the law governing them would be Sharia compliant. To the Muslims, if there is a conflict of laws over a certain issue, reference should be made to the Qur'an for guidance on how to resolve it. The Qur'an emphasises that:

O you who have believed, obey Allah and obey the Messenger and those in authority among you. And if you disagree over anything, refer it to Allah and the Messenger, if you should believe in Allah and the Last Day. That is the best [way] and best in result. ${ }^{55}$

The second is Sharia law may be more suitable to the local social condition and more preferable than adopting the foreign western laws from an entirely different nation. Looking back at the history before the coming of the colonial powers, the law, which applied in Malay states was in fact the Islamic Law, as evidenced in the Malacca Laws. Currently, Sharia law applies only to Muslims in the area of family laws, laws of succession and Sharia criminal law. Considering Malaysia is a mostly Muslim country where the population of Muslims reaches $61.3 \%{ }^{56}$ and the effort to harmonise the civil laws and the Sharia is on-going, it is only right that some kind of reference should be made to the Sharia in reviewing the laws.

\section{Islamic Principle of Justice and the Right to be Heard}

A study by Khairil Azmin and Ashgar Ali (2008) found that it has often been overlooked that Islamic law or Sharia had integrated elements of justice in the administration and settlement of disputes much earlier than the Common Law System and no serious attempt had been made to dissect these elements. ${ }^{57}$ In general, justice in

\footnotetext{
55 Surah An-Nisa' 4:59.

56 Index Mundi, Malaysia religions, January 20, 2018, 8 May $2018<\mathrm{http}: / / w w w$. indexmundi.com/malaysia/religions.html>

57 Khairil Azmin Mokhtar \& Ashgar Ali Ali Mohamed. (2008). Natural justice: The common law and Islamic law approach. The Law Review, 36-52.
} 
any legal system is concerned with the correct implementation of rights and duties (Mohammad H. Kamali, 1993) s8 $^{58}$ and elimination of all injustice and exploitation (M. Ramzan Akhtar, 1992). ${ }^{59}$ As "Allah commands justice and the doing of good"60, Allah (S.W.T.) has provided sufficient guidance in the Qur'an to the believers on how to exercise justice through the institution of legal judgment. ${ }^{61}$ This legal institution ensures that the same standard of criteria will measure everything and if it is monitored properly, it will be impossible for an injustice to occur (Mohammad H. Kamali, 1993). ${ }^{62}$ Overall, these literatures highlight that the need to do justice and to meet a certain procedural standard of justice is fundamental. In the employment context, there is still a lack of study on these matters from the Islamic perspective (Adnan A. Zulfiqar, 2007). ${ }^{63}$

Having reviewed the above, it is time to look at the main sources of reference for the Islamic Law and principle which are the Qur'an and hadith. The researcher examined how the employees' right to be heard should be perceived based on these sources. As for the application of the Islamic law and principle, the researcher looked at the statutory provisions in two Islamic countries, namely the Kingdom of Saudi Arabia (KSA) and the United Arab Emirates (UAE), where Sharia is declared as the source or the main source of their legislations.

The following Qur'anic verses and hadith would point out how fundamental the right to justice is. Allah (S.W.T.) ordered man to be just and trustworthy as evidenced in the Qur'anic verses below:

Allah doth command you to render back your trusts to those to whom they are due, and when you judge between man and man that ye judge with justice. Verily

58 Mohammad H. Kamali. (1993). Fundamental rights of the individual: An analysis of Haqq (Right) in Islamic law. The American Journal of Islamic Social Sciences (10:3). 356-357.

59 M. Ramzan Akhtar. (1992). An Islamic framework for employer-employee relationship. The American Journal of Islamic Social Sciences, (9:2), 202-218.

60 The Qur'an, Surah al-Nahl 16:90.

Țāhā J. al 'Alwānī, \& Yusuf Talal DeLorenzo. (1995) . The rights of the accused in Islam. Arab Law Quarterly (10:1), 3-16.

62 Mohammad H. Kamali, op. cit., 343.

63 Adnan A. Zulfiqar. (2007). Relegious sanctification of labor law: Islamic labor principles and model provisions. U. PA. Journal of Labour and Employment Law (9:2), 421-445. 
how excellent is the teaching which He giveth you! For Allah is He who heareth and seeth all things. ${ }^{64}$

If thou judge, judge in equity between them; for Allah loves those who judge in equity. ${ }^{65}$

O ye who believe! Stand out firmly for Allah as witness to fair dealing, and let not hatred of others to you make you swerve to wrong and depart from justice. Be just: that is next to piety: and fear Allah. For Allah is well acquainted with all that ye do. ${ }^{66}$

There are also detailed descriptions of justice in the Qur'an to enlighten believers on the attitude they have to adopt to exercise justice. True justice in the Qur'an commands man to behave justly without discrimination, to protect other's right, to prohibit violence, to side with the oppressed against the oppressor and to help the needy. ${ }^{67}$ This justice calls for the right of both parties to be protected when reaching a decision in a dispute. Allah (S.W.T.) commands people to rule with justice even if it works against themselves as stated in the Qur'an:

O You who believe! Be upholders of justice, bearing witness for God alone, even against yourselves or your parents and relatives. Whether they are rich or poor, God is well able to look after them. Do not follow your own desires and deviate from the truth. If you twist or turn away, God is aware of what you do. 68

Apart from the verses of the Qur'an, there are a few hadith to support the importance of upholding justice in disputes. As reported by Abu Dawud, Caliph Ali said that the Holy Prophet (S.A.W.) advised him to the effect:

O Ali! People will come to you asking for judgments. When the two parties to a dispute come to you, do not decide in favour of either party until you have heard all

\footnotetext{
64 The Qur'an, Surah An-Nisa (4):57.

65 The Qur'an, Surah Al-Ma'idah (5):42.

66 The Qur'an, Surah Al-Ma'idah (5):8.

67 Harun Yahya (2003). Justice and tolerance in the Qur'an. Singapore: Nickleodeon Books Pte Ltd., at 12.

68 An-Nisa 4:135.
} 
that both parties have to say. Only in this manner will you come to a proper decision, and only in this way will you come to know the truth. ${ }^{69}$

The adherence to justice is not a mere recommendation as there are also sanctions and consequences explained in the Qur'an and hadith for its violation. The Qur'an states:

O Mankind! We created you from male and female, and made you into peoples and tribes so that you might come to know each other. The noblest among you in God's sight is that one of you who best performs his duty. God is All-Knowing, All-Aware. $^{70}$

Thus, the employer neglecting the employees' rights is tantamount to zulm (injustice), which is strictly prohibited in Islam and an employer who takes away rights of workers should be considered an oppressor. ${ }^{71}$ The Prophet (S.A.W.) also warned the employers to "be careful about those who depend on you. Treat them mildly. An owner, who mistreats his servant, shall never enter the portals of paradise." ${ }^{\prime 2}$ Abu Musa also reported Allah's Messenger (S.A.W.) as saying:

Allah the Exalted and Glorious, grant respite to the oppressor. But when He lays Hand upon him, he does not let him off. Re (the Holy Prophet) then recited this verse: Such is the chastisement of thy Lord when $\mathrm{He}$ chastises the towns (inhibited by) wrongdoing persons. Surely, His punishment is painful, severe..$^{73}$

As narrated by Abdullah ibn Abbas when this verse was revealed:

If they do come to thee, either judge between them, or decline to interfere....If thou judge, judge in equity

69 Mohd. Ma'sum Billah \& Ahmad Azam Shariff. (1996). Strict liability? An Islamic jurisprudential response. $C L J$ (4), $1 \mathrm{xv}$.

70 Qur'an, al-Hujarat 49:13.

71 Adnan A. Zulfiqar, op. cit., 435.

72 Majma-uz-zawaid Vol.4 p.236, Kanz-ul-ummal Vol.5 p.18 as cited in Ashgar Ali Ali Mohamad and Farheen Baig Sardar Baig. (2012). Treatment of migrant workers: The Islamic perspective. Australian Journal of Basic and Applied Sciences (6:11), 97-105.

73 Sahih Muslim, Book 32, Hadith no. 6253, Ch.13. 
between them." Banu an-Nadir used to pay half bloodmoney if they killed anyone from Banu Qurayzah. When Banu Qurayzah killed anyone from Banu anNadir, they would pay full blood-money. So the Apostle of Allah (S.A.W) made it equal between them (Sunan Abu Dawud, 18:3584). The divine order, revealed in the Qur'an and manifested in the Prophet's words and deeds, will last unchanged and in this sense it should be emphasised once again that it becomes a necessary obligation (wajib) on the believers. ${ }^{74}$

Bearing on the fact that the right to be heard is based on the fundamental legal right to justice and it is clear from the hadith above that the accused's right to be heard must be granted and it is not a mere recommendation, it may be submitted here that from the Islamic perspective, the employee's right to be heard in a quasijudicial making process like a domestic enquiry is mandatory.

Having discussed the Islamic principle of justice as the foundation for the right to be heard and its mandatory effect, the following discussion will outline the subsequent duty that arises on the part of the judges ${ }^{75}$ and employers as mentioned in the Qur'an and hadith. They clearly support the mandatory effect of the employees' right to be heard. A judge must have knowledge of Islamic Law and jurisprudence and the rule of procedure, and must be able to decide and settle disputes accordingly. ${ }^{76}$ Competent and just judges are just as important as accurate proof and unshakable evidence to achieve legal justice. ${ }^{77}$ Accordingly, it would be the role of a judge to ensure that the evidence is strong based on the process of Islam law. As Narrated by Abdullah, Allah's Apostle said, "Do not wish to be like anyone, except in two cases: (a) a man whom Allah has given wealth and spends it righteously, and (b) a man whom Allah has given wisdom (knowledge of the Qur'an and the Hadith) and he acts according to it..." ${ }^{78}$ The second case must be referring to, among others, a judge. The Qur'an emphasises the importance of the investigation carried out by judges in order to find out the truth in

\footnotetext{
74 Smirnov, A. (1996). Understanding justice in an Islamic context: Some points of contrast with Western theories. Philosophy East and West (46:3), 337-350.

75 In the context of disciplinary proceedings, this is referring to the disciplinary committee.

76 The Mejelle, Article 1793.

77 Khairil Azmin Mokhtar \& Ashgar Ali Ali Mohamed, op. cit., 43.

78 Bukhari, Sahih Bukhari, Book 89, Hadith no. 255.
} 
the administration of justice as it says "O ye who believe, if a wicked person comes to you with any news, ascertain the truth, lest ye harm people unwittingly, and afterwards become full of repentance for what ye have done." 79 All tittle-tattles or reports are to be tested and the truth ascertained to avoid any scandal or slander of all kinds. ${ }^{80}$ This is further supported by another hadith narrated by Abu Dawud. Caliph Ali said that the Holy Prophet (S.A.W.) sent him to Yemen as judge and advised him to the effect:

O Ali! People will come to you asking for judgments. When the two parties to a dispute come to you, do not decide in favour of either party until you have heard all that both parties have to say. Only in this manner will you come to a proper decision, and only in this way will you come to know the truth. ${ }^{81}$

Moral sanctions may also be invoked when one, acting as a 'judge' in a dispute or in the employment law context relevant to this research, or acting as a committee member in an employee's disciplinary action, fails to carry out his or her duty. The following hadith by the Prophet (S.A.W.) explained the consequences of failing to carry out one's duty as a judge as he stated that:

Judges are of three types, one who will go to paradise and two to hell. The one to go to paradise is a man who knows what is right and gives judgment accordingly, but a man who knows what is right and acts tyrannically in his judgment will go to hell, and a man who gives judgment when he is ignorant will go to hell. ${ }^{82}$

The above evidence from the Qur'anic verses and hadiths clearly support the idea that as a part of the process of ascertaining the truth or the investigation process, the other party to the dispute must be heard. Then only the decision would be considered as proper. They are clear prohibitions for a judge to make a decision before both sides are heard. Accordingly, members of the disciplinary committee, who act as judges, must guarantee that both parties to the proceedings are heard before passing any judgment. It is their duty to ensure that the

\footnotetext{
79 Surah al-Hujarat 49:6.

80 Abdullah Yusuf Ali, The meaning of the holy Qur'an: Text, translation and commentaries. (Kuala Lumpur, Islamic Book Trust, 2005), 1119.

${ }^{81}$ Abu Dawud, Sunan Abu Dawud, Book 18, Hadith No. 3575.

82 Id., Hadith No. 3566.
} 
evidential rules contained in the Islamic law are observed. A just decision can never be achieved unless 'clear proof' and arguments have been presented and the litigating parties have been given the proper opportunity to prove their facts and to defend their rights. ${ }^{83}$ The curable principle, as applied in Malaysia, which allows the employer to dismiss the employee without an enquiry, shall have no place under the Sharia.

Another support for the mandatory effect of a pre-dismissal right can also be found in the Mejelle. The Mejelle or Al-Majalla Al-Ahkam Al Adaliyyah is the Ottoman's 'codification' of the Sharia concepts and rules on civil matters compiled by jurists and promulgated in $1286 \mathrm{H}$ (1836 A.D.). Even though the Mejelle was never expressly recognised as law in any of the Gulf jurisdictions, in practice it became the ad hoc civil code in those jurisdictions ${ }^{84}$ before the modern codes were formed. It remains as an extremely important reference in Islamic Law and was applied in most of the Arab countries that were under

the Ottoman rule until their independence after the First World War when they promulgated their own civil codes ${ }^{85}$ It is obvious from the literal reading of art 1816 of the Mejelle that the right to be heard is also a mandatory right. The article is laid down below:

When the parties are present in Court for the purpose of the trial, the judge shall first of all call upon the plaintiff to state his case. If he has previously reduced his claim to writing it shall be read over and confirmed by the plaintiff. He shall then call upon the defendant to answer. Thus, he shall inform the defendant that the plaintiff makes such and such claims against him, and shall ask the defendant to reply.

It should be noted that even though the article above is concerned with a court's trial, the right should also be treated likewise in a quasi-judicial disciplinary proceeding or a domestic enquiry prior to a dismissal of any employee.

83 Khairil Azmin Mokhtar \& Ashgar Ali Ali Mohamed, op. cit., 46.

${ }^{84}$ Ballantyne, W. M. (1986). The new civil code of the UAE: A further reassertion of the Sharia. Arab Law Quarterly (1:3), 245-246.

85 British Institute of International and Comparative Law, 'Introduction to Islamic Law', http://www.biicl.org/files/777_introduction_to_islamic_law.pdf. (accessed 25 January 2015). 


\section{Application in the Kingdom of Saudi Arabia and the United Arab Emirates}

It may be observed that unlike Malaysia where different employment laws apply between the public and the private sector, in KSA, Labour Law (Royal Decree No. M/51) 2006 or better known as Labour Law 2006 (LL 2006) applies to both sectors with exceptions to certain categories of workers as listed in art (7) of the statute. ${ }^{86}$ The Royal Decree No. 49 of 1977 allows the public service to promulgate further its own regulations ${ }^{87}$ but for the present purpose, the discussion of the legal provisions on the right to be heard in KSA will be based mainly on LL 2006. The mandatory procedural aspect of the disciplinary action in KSA employment is clearly indicated in art (71) LL 2006 where it states:

Disciplinary action may not be imposed on a worker except after notifying him in writing of the allegations, interrogating him, hearing his defense and recording the same in minutes to be kept in his file. The interrogation may be verbal in minor violations, the penalty for which does not go beyond a warning or a deduction of one-day's is salary. This shall be recorded in minutes.

The mandatory effect of the right to be heard, which consists of the right to a proper notice and a proper trial, could not have been more evidently stated as the requirement of notice and the hearing of the employee's defence are expressly stipulated in the above provision. These requirements must be complied with before any of the disciplinary penalties under art (66) of the same statute is imposed on the employee.$^{88}$ The disciplinary procedures are minimal yet clearly dictated and do not require a reading between the lines of a mere two words of 'due enquiry' as in s 14(1) of the Malaysian Employment Act 1955. Another feature worth highlighting is cases which are considered as serious misconducts meriting dismissal are

86 They are the agricultural workers, domestic workers, seafarers, sportsmen and employer's family members.

87 The Civil Service Regulations can be found in Umm Al-Qura, 82:4068 (2005), 5-17.

88 Those penalties include warning, fines, withholding allowance, postponement of promotion, suspension from work and dismissal in cases set forth by the law. 
spelled out by the law in art (80) LL 2006. Those cases are listed together with another reinforcement that the employer facing those cases is under a legal obligation to give the employee "a chance to state his reasons for objecting to the termination." This may work as a second guarantee that the dismissal will only be lawful if the employee's right to be heard is observed.

Turning now to the UAE's statutory provisions, the main labour legislation for the employee in the private sector is the Federal law No.8 on the Regulations of Labour Relations 1980 (FLLR 1980) while the civil servants are subjected to the Federal Decree Law No.11 for 2008 on Human Resources in the Federal Government. ${ }^{89}$ Just like KSA, the mandatory state of the right to be heard in disciplinary proceedings in the UAE's private sector employment is also not in question anymore. Art (110) FLLR 1980 expressly provides:

Any of the penalties prescribed in art 102 may not be applied on the employee unless he is notified in writing of the charge taken against him and unless his statement is heard and his defence is investigated and unless all that is recorded in a report kept in his personal file...

It can be observed from the above provision, the requirements of notice and the hearing of the employee's statement and defence indicate the mandatory effect of his right to be heard before any penalty ${ }^{90}$ can be imposed on him.

Amended by Federal Decree Law No. (9) for 2011 and Federal Decree Law No. (17) for 2017.

90 The penalties are listed in art (102). The article provides "disciplinary penalties which may be imposed by the employer or its agent upon its employees are as follows:

1. Warning

2. Fine

3. Suspension from work with reduced pay for a period not exceeding ten days.

4. Forfeiture of deferment of periodic increment in establishments where such increment system is applied.

5. Forfeiture or deferment of promotion in establishments where the promotion system is applied.

6. Dismissal from service but reserving right to end of service benefits.

7. Dismissal from service together with forfeiture of all or part of the benefits, provided that penalties shall not be imposed for reasons other than those specifically prescribed in Article (120) of this Law. 
With respect to the employee's right to be heard in the UAE's civil service, the executive rule of the Decree by the Federal Law No.11, year 2008 for Federal Government Human Resources and amendments provide that any administrative punishment shall not be imposed on the employee "unless after carrying written investigation with him and given good opportunity to hear his statements and defence." ${ }^{.11}$ It is also clear that this provision indicates that in case of misconduct, there must be an investigation and the public servant must also be afforded the right to be heard before he is penalised. The right is a mandatory right.

It is clear in Islam that legal as well as moral institution in synchrony, uphold the right to be heard to be a mandatory right. The accused right to be heard in Islam is very much the same with the principle of natural justice, the claimant must prove that the accused is guilty and not the accused must prove that he is innocent. That is why the accused, as in this context, the employee, must be given the right to be heard to answer the evidence which are used against him before he is dismissed and not afterward the Industrial Court's proceedings.

The curable principle as applied in Malaysia can be strongly argued to be against the Sharia. The Sharia guarantees the right to a defence and prohibits its denial under any circumstances except where there is an admission of guilt by the accused employee..$^{92}$ It may also be observed that there is no exception stated anywhere in KSA and the UAE's statutory provisions where the pre-dismissal right of the employee may be dispensed. As opposed to the legal position in Malaysia, there are several exceptions to the application of the right to be heard. ${ }^{93}$

It should be noted that similar with KSA, the offences meriting dismissal are ascertained and clearly listed in art (120) FLLR 1980.

91 art (91(5)) of the Cabinet Resolution No.13, year 2012.

92 Mahmud Saedon A. Othman. (2000). An introduction to Islamic law of evidence, Trans: Raden Ahmad Shauki R. Hisan. Kuala Lumpur: The open Press (M) Sdn. Bhd., at 31.

93 Refer art 135(1) read with art 132 of the Malaysian Constitution where these provisions exclude the Armed Forces services of the right to be heard. Also refer art 135(2) of the Malaysian Constitution. The other exception is when the employee is dismissed on account of a criminal offence for which conviction has been secured in a court of law (refer Malaysia Airlines Systems Bhd v Ramli Daud [2000] 2 ILR 319). 


\section{CONCLUSION}

Overall, there are a few notable differences between the Islamic countries' and Malaysia's statutory provisions. KSA and the UAE have clear statutory provisions indicating the right to be heard as a mandatory right in both the private and the public sector employment whereas in Malaysia, only the public service sector has a clear statutory provision guaranteeing the right. It is especially provided by regulation 34 and 37, Public Officers (Conduct and Discipline) Regulations 1993. The employees in the private sector who are covered by the Employment Act 1955 may to a certain extent be accorded the right but not for the others. Nevertheless, it is so unfortunate that for as long as the curable principle applies, there is no definite guarantee that employees in Malaysia have the procedural protection before dismissal. This holds true despite the argument that s 20(1) Industrial Relations Act 1967 may be construed to require the procedural fairness element.

It may be concluded this far that the issue of whether or not a domestic enquiry is mandatory remains unsettled in the private sector employment in Malaysia due to the followings facts: (a) vaguely defined statutory right to procedural fairness under s 20 of the Industrial Relations Act 1967 and (b) the uncertain application of the curable principle despite a rather obvious statutory requirement of due enquiry under s 14(1) of the Employment Act 1955. Therefore, a provision exacting the mandatory effect of the right in the Industrial Relations Act 1967 is highly recommended to cover those who do not fall under the ambit of the Employment Act 1955. The basic procedural elements of the enquiry should also be included in the provision to ensure uniformity of the application of the right to be heard in Malaysia. It should also be emphasised that the application of the curable principle should be very limited if not discarded altogether considering the weak foundations in backing up the principle. The judges should not be too ready to accord the curable principle to the status of a doctrine. They should consistently insist on the pre-dismissal enquiry. This would, in turn, educate the employer to adhere to the rule. Should there be any doubt on how to treat this right, Malaysia should take into account the Islamic perspective on this matter.

Essentially, the law needs to be reviewed and amended, if necessary to ensure procedural rectitude in dismissal proceedings. The amendment should include specific statutory provisions governing 
the mandatory effect of the domestic enquiry and its procedures. This is to ensure that domestic enquiry is properly carried out and justice is done. Considering that the Industrial Relations Act 1967 is especially ambiguous on the pre-dismissal right and procedures, a specific clause requiring the mandatory pre-dismissal enquiry in the Act should be constructed. It may be combined together with its most fundamental procedures as constructed in the Labour Law provisions in the Islamic countries. Based on the statutory guidelines from the Islamic countries above, the construction of the provision to be inserted in the Industrial Relations Act 1967 may appear as below:

A workman may not be dismissed except after he is notified in writing with theallegation, his statement is heard and he is given the opportunity to defend himself that his defence is investigated.

It may be inserted as s 20 (1B) of the existing Act. As for the Employment Act 1955, the fundamental procedural requirements may be inserted as ss 14 (1A) of the existing provision and may read as below:

Any of the penalties prescribed in s 14(1) may not be applied on the employee except after he is notified in writing with the allegation, his statement is heard and he is given the opportunity to defend himself that his defence is investigated.

\section{REFERENCES}

Abdullah Yusuf Ali. (2005). The meaning of the Holy Qur'an: Text, translation and commentaries. Kuala Lumpur: Islamic Book Trust.

Abu Dawud, Sunan Abu Dawud. Retrieved http://www.sunnah.com /abudawud/.

Adnan A. Zulfiqar. (2007). Religious sanctification of labor law: Islamic labor principles and model provisions. U. PA. Journal of Labour and Employment Law, 9(2), 421-445.

Anantaraman, V. (1997). Malaysian industrial relations, law \& practice. Selangor, Malaysia: Universiti Putra Malaysia Press. 
Anwarul Yaqin. (1999). Procedural fairness in dismissals for misconduct: Some reflections on judicial trends in Malaysia. MLJA (2), 140-156.

Ashgar Ali Ali Mohamad \& Farheen Baig Sardar Baig. (2012). Treatment of migrant workers: The Islamic perspective. Australian Journal of Basic and Applied Sciences, 6(11), 97105.

Ayadurai, D. (1998). Industrial relations in Malaysia. Kuala Lumpur: Malayan Law Journal Sdn Bhd.

Balakrishnan, M., \& Balakrishnan, P. (2007). Misconduct, domestic enquiry and the rules of natural justice in the context of Malaysian employment relations. MLJA (6), 149-163.

Ballantyne, W. M. (1986). The new civil code of the UAE: A further reassertion of the Sharia. Arab Law Quarterly, 1(3), 245-246.

British Institute of International and Comparative Law . 'Introduction to Islamic Law', Retrieved from ,http://www.biicl.org/ files/777 introduction to islamic law.pdf

Bukhari, Sahih Bukhari, [website], https://sunnah.com/bukhari

CCH HR Editors. (2010). Malaysia workplace misconduct law and practice. Malaysia: $\mathrm{CCH}$ Asia Pte Limited.

Esposito, J. L. The Oxford Dictionary of Islam, [website], http;// www.oxfordislamicstudies.com/article/opr/t125/e1459

Fawzi Mubarak Al Kiyumi. (2013). Unfair dismissal study in Omani labour law with emphasis on the relevance of Shari'a' Ph.D Thesis, University of Bedfordshire.

Harun Yahya. (2003). Justice and tolerance in the Qur'an. Singapore: Nickleodeon Books Pte Ltd.

Hew, S. K. (2013). Dismissal: Salient point to ponder before industrial court proceedings in Malaysia ( $2^{\text {nd }}$ ed.). Selangor, Malaysia: Leeds Publication.

Kamal Halili Hassan. (2001). Siasatan domestik: Trend dan pendirian mahkamah perusahaan, 1995-2001, ILR (4), i-x.

Khairil Azmin Mokhtar \& Ashgar Ali Ali Mohamed. (2008). Natural justice: The common law and Islamic law approach. The Law Review, 36-52.

M. Ramzan Akhtar. (1992). An Islamic framework for employeremployee relationship. The American Journal of Islamic Social Sciences 9(2), 202-218.

Mahmud Saedon A. Othman. (2000). An introduction to Islamic law of evidence, Trans: Raden Ahmad Shauki R. Hisan. Kuala Lumpur: The Open Press (M) Sdn. Bhd. 
Maimunnah Aminuddin. (2013). Malaysian industrial relations \& employment Law ( $8^{\text {th }}$ ed.). Malaysia: McGraw Hill Education (Malaysia) Sdn. Bhd.

Mohammad H. Kamali. (1993). Fundamental rights of the individual: An analysis of Haqq (right) in Islamic law. The American Journal of Islamic Social Sciences 10(3). Retrieved from, http://www.i-epistemology.net/v1/law/469.

Mohd. Ma'sum Billah., \& Ahmad Azam Shariff. (1996). Strict liability? An Islamic jurisprudential response. $C L J(4), 1 \mathrm{xv}$.

Mohd. Ma'sum Billah. (2006). Shari'ah standard of business contract. Kuala Lumpur, Malaysia: A.S. Noordeen.

Pathmanathan, N., Kanagasabai, S. K., \& Alagaratnam, S. (2003). Law of dismissal. Singapore: $\mathrm{CCH}$ Asia Pte Limited.

Muslim, Sahih Muslim. Retrieved from https://sunnah.com/muslim. Smirnov, A. (1996). Understanding justice in an Islamic context: Some points of contrast with western theories. Philosophy East and West 46(3), 337-350.

Sundra-Karean, V. (2012). Employment law and theory. Malaysia: The Malaysian Current Law Journal Sdn Bhd.

Taha J. al 'Alwani \& Yusuf Talal DeLorenzo. (1995). The rights of the accused in Islam. Arab Law Quarterly 10(1), 3-16. 